\title{
Lsi2: A black box in plant silicon transport
}

\author{
Devrim Coskun (D) Rupesh Deshmukh • \\ S. M. Shivaraj · Paul Isenring • \\ Richard R. Bélanger
}

Received: 13 April 2021 / Accepted: 22 June 2021 / Published online: 10 July 2021

(C) The Author(s) 2021

\begin{abstract}
Background Silicon (Si) is widely considered a nonessential but beneficial element for higher plants, providing broad protection against various environmental stresses (both biotic and abiotic), particularly in species that can readily absorb the element. Two plasmamembrane proteins are known to coordinate the radial transport of $\mathrm{Si}$ (in the form of $\mathrm{Si}(\mathrm{OH})_{4}$ ) from soil to xylem within roots: the influx channel Lsi1 and the efflux transporter Lsi2. From a structural and mechanistic perspective, much more is known about Lsi1 (a member of the NIP-III subgroup of the Major Intrinsic Proteins) compared to Lsi2 (a putative $\mathrm{Si}(\mathrm{OH})_{4} /$ $\mathrm{H}^{+}$antiporter, with some homology to bacterial anion transporters).
\end{abstract}

Responsible Editor: Ismail Cakmak.

D. Coskun · R. R. Bélanger $(\bowtie)$

Département de Phytologie, Faculté Des Sciences de L'Agriculture Et de L'Alimentation (FSAA), Université Laval, Québec, Québec, Canada

e-mail: richard.belanger@fsaa.ulaval.ca

R. Deshmukh · S. M. Shivaraj

National Agri-Food Biotechnology Institute (NABI),

Mohali, India

S. M. Shivaraj

CSIR-National Chemical Laboratory, Pune, India

P. Isenring

Département de Médecine, Faculté de Médecine,

Université Laval, Québec, Québec, Canada
Scope Here, we critically review the current state of understanding regarding the physiological role and molecular characteristics of Lsi2. We demonstrate that the structure-function relationship of Lsi2 is largely uncharted and that the standing transport model requires much better supportive evidence. We also provide (to our knowledge) the most current and extensive phylogenetic analysis of Lsi2 from all fully sequenced higher-plant genomes. We end by suggesting research directions and hypotheses to elucidate the properties of Lsi2.

Conclusions Given that Lsi2 is proposed to mediate xylem Si loading and thus root-to-shoot translocation and biosilicification, it is imperative that the field of Si transport focus its efforts on a better understanding of this important topic. With this review, we aim to stimulate and advance research in the field of Si transport and thus better exploit Si to improve crop resilience and agricultural output.

Keywords Silicon $\cdot$ Lsi2 $\cdot$ Efflux $\cdot$ Membrane transport $\cdot$ Xylem loading $\cdot$ Root-to-shoot translocation

\section{Introduction}

The field of plant silicon ( $\mathrm{Si}$ ) biology has garnered tremendous attention, particularly in the past two decades. This can be attributed to the growing realization that, despite being considered a non-essential 
element (with the possible exception for the Equisetaceae), Si is now officially regarded as a beneficial element since it confers many plants with heightened resilience against environmental stress, both biotic and abiotic (Epstein 1994; 1999; Liang et al. 2015; Coskun et al. 2019a). The extent to which plants benefit from Si relies upon its accumulation in tissues, which typically varies from $c .0 .1 \%$ to $10 \%$ (on a dryweight basis), and displays strong cultivar, species, and larger phylogenetic differences (Epstein 1994; Ma 2004; Hodson et al. 2005; Trembath-Reichert et al. 2015; Coskun et al. 2019a; Deshmukh et al. 2020). Although the precise mechanistic properties of $\mathrm{Si}$ in plants remain elusive and contentious, it has recently been argued that contrary to current orthodoxy, the bioavailable form of $\mathrm{Si}$ (i.e., silicic acid $\left(\mathrm{Si}(\mathrm{OH})_{4}\right)$ ) has little if any intracellular role; rather, its deposition as silica $\left(\mathrm{SiO}_{2}\right.$, via biosilicification; Belton et al. 2012; Kumar et al. 2020) within the extracellular matrix (particularly within the root endodermal and shoot tissues) acts simply as a protective agent against the numerous environmental stressors plants encounter (Coskun et al. 2019a, b).

From a wider perspective, the global biogeochemical cycling of $\mathrm{Si}$, which is intricately coupled to the global carbon (C) cycle, is critically dependent on plants (Street-Perrott and Barker 2008; Struyf et al. 2009; Carey and Fulweiler 2012; de Tombeur et al. 2020; Tan et al. 2021). As Raven (2003) noted, the Poaceae (among the highest Siaccumulating angiosperm families) fix $c .15 \mathrm{Pg} \mathrm{C}$ per year out of c. $60 \mathrm{Pg} \mathrm{C}$ per year (i.e., c. 25\%) of net primary production on land. Meanwhile, the decomposition of $\mathrm{Si}$-accumulating plants returns $\mathrm{Si}$ to the oceans, where diatoms (for which $\mathrm{Si}$ is essential) fix $>15 \mathrm{Pg} \mathrm{C}$ per year out of c. $50 \mathrm{Pg}$ $\mathrm{C}$ per year $(>30 \%)$ of net primary production in oceans.

In rice (Oryza sativa L.), two genes, OsLsil and OsLsi2 (Low silicon $\underline{1}$ and $\underline{2}$, named after the low $\mathrm{Si}$ content observed in tissues of the respective lossof-function mutants), are known to dictate the radial transport of Si from soil to xylem through their presence in roots (Ma et al. 2006, 2007; Ma and Yamaji 2015). These genes code for plasma-membrane transporters that are proposed to act in coordination in the symplastic movement of $\mathrm{Si}$ to bypass apoplastic (Casparian band) barriers of the exodermis and endodermis. Specifically, OsLsi1 is expressed in the distal end of exodermal and endodermal cells and mediates the thermodynamically passive uptake of $\mathrm{Si}(\mathrm{OH})_{4}$, whereas OsLsi2 is expressed in the proximal end of the same cells and mediates the secondary active efflux of $\mathrm{Si}(\mathrm{OH})_{4}$ in exchange for protons $\left(\mathrm{H}^{+}\right)$(Ma and Yamaji 2015; Fig. 1). In other species where this model has been tested, Lsil can display a much wider expression profile (including in epidermal and cortical cell layers), whereas Lsi2 appears to be predominantly expressed in the endodermis (Table 1). In fact, thus far, only rice has been shown to display such specific polar and cellular localization of Lsi1 and
Fig. 1 The standing Sitransport model in the roots of rice (Oryza sativa). Lsi1 and Lsi 2 are expressed in the distal and proximal ends, respectively, of the exodermis and endodermis. Lsi1 mediates the thermodynamically passive uniport of $\mathrm{Si}(\mathrm{OH})_{4}$, whereas Lsi 2 is thought to mediate the secondary active transport of $\mathrm{Si}(\mathrm{OH})_{4}$ in antiport with $\mathrm{H}^{+}$ (the electrochemical gradient of which is generated by the plasma-membrane $\mathrm{H}^{+}$-ATPase). Redrawn from Ma and Yamaji (2008)

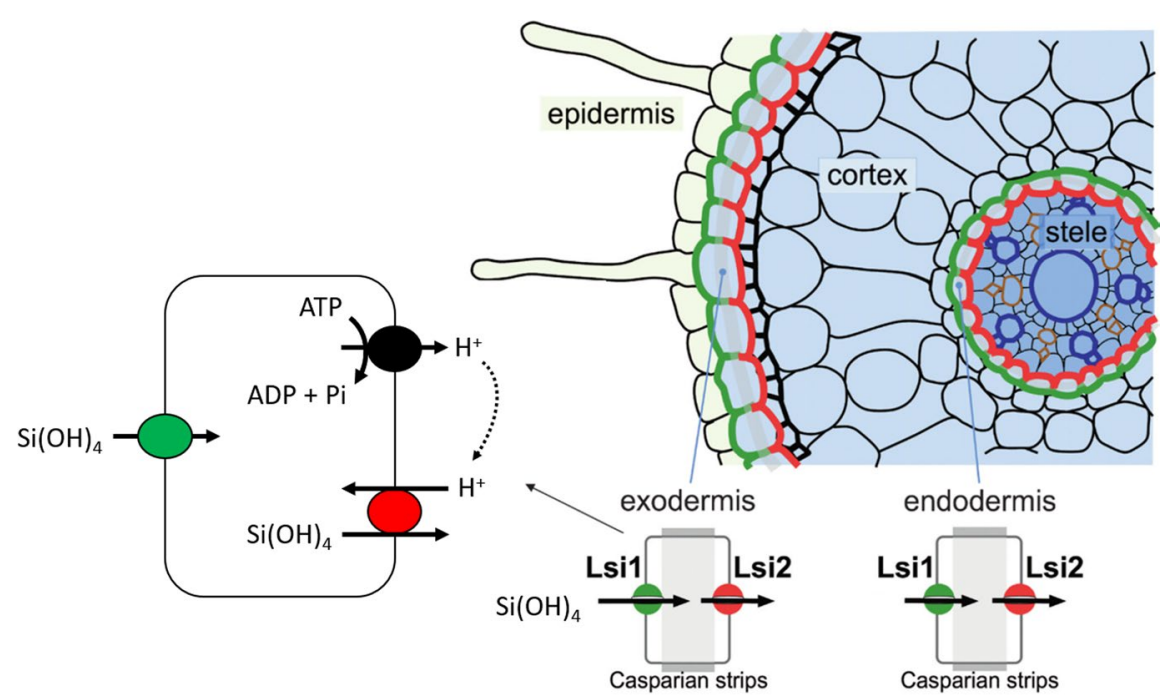


Lsi 2 and this feature has been proposed to explain the high accumulation of $\mathrm{Si}$ in shoot tissues (Mitani-Ueno and Ma 2020; see 'Protein localization' subsection, below).

While much is known about the protein structure, transport function, and physiological role of Lsil, the same cannot be said of Lsi2 in these regards. The influence of Lsil on tissue $\mathrm{Si}$ content is also better known than that of Lsi2. Yet, understanding Lsi2 is critical given that it appears to influence all downstream processes, from root-to-shoot translocation to biosilicification.

Here, we critically review the current state of understanding regarding the phylogeny, protein structure, functional determinants, transport mechanism, and physiological role of Lsi2. Throughout, we discuss several important but hitherto underexplored research questions: What is the role of Lsi2 and is it indeed necessary for $\mathrm{Si}$ accumulation in planta? What is the expression profile of Lsi2? And what

Table 1 Literature survey of Lsil and Lsi2 gene expression responses to Si supplementation and associated protein (tissue and cellular) localization in roots of those species where both genes have been studied

\begin{tabular}{|c|c|c|c|c|c|}
\hline Species & Gene & $\begin{array}{l}\text { Gene expression } \\
\text { response to } \mathrm{Si}\end{array}$ & $\begin{array}{l}\text { Protein tissue locali- } \\
\text { zation }\end{array}$ & $\begin{array}{l}\text { Protein cellular } \\
\text { localization }\end{array}$ & Reference \\
\hline \multirow[t]{2}{*}{ Rice (Oryza sativa) } & OsLsil & $\begin{array}{l}\text { Downregulated } \\
\text { Upregulated }^{2}\end{array}$ & Basal root & $\begin{array}{l}\text { Distal end of exoder- } \\
\text { mis and endoder- } \\
\text { mis }\end{array}$ & $\begin{array}{l}{ }^{1} \text { Ma et al. } 2006 \\
{ }^{2} \text { Kim et al. } 2014\end{array}$ \\
\hline & OsLsi2 & $\begin{array}{l}\text { Downregulated } \\
\text { Upregulated }^{2}\end{array}$ & $\begin{array}{l}\text { Main and lateral } \\
\text { roots (not in root } \\
\text { hairs) }\end{array}$ & $\begin{array}{l}\text { Proximal end of } \\
\text { exodermis and } \\
\text { endodermis }\end{array}$ & $\begin{array}{l}{ }^{1} \text { Ma et al. 2007; } \\
\text { Yamaji and Ma } \\
2011 \\
{ }^{2} \text { Kim et al. } 2014\end{array}$ \\
\hline \multirow[t]{2}{*}{ Maize (Zea mays) } & ZmLsil & $\begin{array}{l}\text { Unaffected }^{1} \\
\text { Downregulated }^{2}\end{array}$ & Basal root & $\begin{array}{l}\text { Distal end of epider- } \\
\text { mis, hypodermis, } \\
\text { and cortex }\end{array}$ & $\begin{array}{l}{ }^{1} \text { Mitani et al. 2009a } \\
{ }^{2} \text { Bokor et al. } 2015\end{array}$ \\
\hline & ZmLsi2 & Downregulated & Basal root & $\begin{array}{l}\text { Endodermis (no } \\
\text { polarity) }\end{array}$ & $\begin{array}{l}\text { Mitani et al. 2009b; } \\
\text { Bokor et al. } 2015\end{array}$ \\
\hline \multirow[t]{2}{*}{$\begin{array}{l}\text { Barley (Hordeum } \\
\text { vulgare) }\end{array}$} & HvLsil & Unaffected & Basal root & $\begin{array}{l}\text { Distal end of } \\
\text { epidermis and } \\
\text { cortex, lateral root } \\
\text { hypodermis }\end{array}$ & $\begin{array}{l}\text { Chiba et al. 2009; } \\
\text { Hosseini et al. } \\
2017\end{array}$ \\
\hline & HvLsi2 & Downregulated & Basal root & $\begin{array}{l}\text { Endodermis (no } \\
\text { polarity) }\end{array}$ & $\begin{array}{l}\text { Mitani et al. 2009b; } \\
\text { Hosseini et al. } \\
2017\end{array}$ \\
\hline \multirow[t]{2}{*}{$\begin{array}{l}\text { Pumpkin (Curcur- } \\
\text { bita moschata) }\end{array}$} & CmLsil & n.d & Throughout root & $\begin{array}{l}\text { Throughout root (no } \\
\text { polarity) }\end{array}$ & Mitani et al. 2011 \\
\hline & CmLsi2 & n.d & Throughout root & n.d & $\begin{array}{l}\text { Mitani-Ueno et al. } \\
2011\end{array}$ \\
\hline \multirow[t]{2}{*}{$\begin{array}{l}\text { Cucumber (Cucumis } \\
\text { sativus) }\end{array}$} & CsLsil & Downregulated & Root tips & $\begin{array}{l}\text { Epidermis and } \\
\text { cortex (no polar- } \\
\text { ity), distal end of } \\
\text { endodermis }\end{array}$ & Sun et al. 2017 \\
\hline & CsLsi2 & Upregulated & n.d & $\begin{array}{l}\text { Endodermis (no } \\
\text { polarity) }\end{array}$ & Sun et al. 2018 \\
\hline \multirow[t]{2}{*}{$\begin{array}{l}\text { Horsetail (Equise- } \\
\text { tum arvense) }\end{array}$} & EaLsil $($ EaNIP3;1) & $\begin{array}{l}\text { Unaffected (in trans- } \\
\text { formed Arabidop- } \\
\text { sis thaliana) }\end{array}$ & n.d & n.d & Grégoire et al. 2012 \\
\hline & EaLsi2 & Unaffected & n.d & n.d & Vivancos et al. 2016 \\
\hline \multirow[t]{2}{*}{$\begin{array}{c}\text { Tomato (Solanum } \\
\text { lycopersicum) }\end{array}$} & SlLsil & Unaffected & Throughout root & $\begin{array}{l}\text { Throughout root (no } \\
\text { polarity) }\end{array}$ & Sun et al. 2020 \\
\hline & SlLsi2 & Unaffected & n.d & n.d & Sun et al. 2020 \\
\hline
\end{tabular}

n.d., not determined 
is the mechanism of transport of Lsi2 and how is it regulated? We argue that much remains to be learned, especially when compared to Lsi1, and that many of the ideas proposed after the initial characterization of Lsi2 have not been subsequently challenged in the literature. If we are to effectively exploit $\mathrm{Si}$ to improve plant resilience to environmental stress, particularly in the context of the agricultural response to climate change, it is important that we better understand the fundamental mechanisms of Si acquisition in plants, including the role of Lsi2.

\section{Lsi1: A juxtaposition}

Before discussing Lsi2, a brief review of Lsi1 is warranted to highlight the vast discrepancy in understanding between the two transporters. The influx channel Lsil is a member of the Nodulin26-like intrinsic protein-III (NIP-III) subgroup of the Major Intrinsic Proteins (MIPs; also known as aquaporins) which mediates the thermodynamically passive transport of $\mathrm{Si}(\mathrm{OH})_{4}$, as well as other metalloids, including boron $\left(\right.$ as $\left.\mathrm{B}(\mathrm{OH})_{3}\right)$ and arsenic $\left(\right.$ as $\left.\mathrm{As}(\mathrm{OH})_{3}\right)(\mathrm{Ma}$ et al. 2006; 2008; Mitani-Ueno et al. 2011). First described in rice, OsLsil (OsNIP2;1) was found to be expressed predominately on the distal side of exodermal and endodermal cell plasma membranes in root cross-sections, and the basal portion of seminal and lateral roots, longitudinally (Ma et al. 2006; Yamaji and Ma 2007). Since then, OsLsil homologs have been cloned and characterized from several species, including maize (Zea mays; Mitani et al. 2009a), barley (Hordeum vulgare; Chiba et al. 2009), pumpkin (Curcurbita moschata; Mitani et al. 2011), wheat (Triticum aestivum; Montpetit et al. 2012), horsetail (Equisetum arvense; Grégoire et al. 2012), soybean (Glycine max; Deshmukh et al. 2013), poplar (Populus trichocarpa; Deshmukh et al. 2015), cucumber (Cucumis sativus; Sun et al. 2017), tobacco (Nicotiana sylvestris; Coskun et al. 2019c), date palm (Phoenix dactylifera; Bokor et al 2019), grape (Vitis vinifera; Noronha et al. 2020), and tomato (Solanum lycopersicum; Deshmukh et al. 2015; Sun et al. 2020).

Interestingly, OsLsil expression was also found to be downregulated in rice in response to several days of Si supplementation in the rooting media (Ma et al. 2006). However, this response appears to vary across other species. In addition, the patterns of cellular/tissue localization have also been seen to differ across plants. As Table 1 shows, Lsil and Lsi2 expression can be either suppressed, enhanced, or unaffected by $\mathrm{Si}$, depending on the species; similarly, protein localization can vary widely.

Like all members of the MIPs, Lsi1 is composed of a tetramer with each subunit composed of six transmembrane domains and two half-transmembrane helices protruding from opposite ends towards the centre of the pore where a constriction site composed of two conserved NPA (Asp-Pro-Ala) domains is formed (Murata et al. 2000; Pommerrenig et al. 2015). A second constriction site, termed the selectivity filter, is composed of four amino acids, and is involved in solute specificity for given MIP subgroups (Hove and Bhave 2011).

For Lsi1, the selectivity filter is composed of a conserved GSGR (Gly-Ser-Gly-Arg) motif that confers selectivity for Si (Mitani-Ueno et al. 2011). The horsetail EaLsil (a NIP-II member) is an exception, with a selectivity filter composed of a STAR (SerThr-Ala-Arg) motif (Grégoire et al. 2012). Deshmukh et al. (2015) noticed that some species, such as tomato, possess an Lsi1 channel, but nevertheless accumulate little $\mathrm{Si}$ in their tissues (c. 0.2\%), and attributed this peculiarity to an extra amino acid (aa) between the NPA domains (i.e., 109 instead of the common 108 found in Si-accumulating species) which renders the channel much less permeable to Si. Sun et al. (2020) reported SILsil from tomato to be Si-permeable (and attributed the low-Si phenotype in planta to a Si-impermeable Lsi2) but the rates of influx were indeed much lower than what is typically seen for Lsi1s from Si-accumulating species (e.g., rice, barley, soybean, etc.), suggesting perhaps the relationship between Lsil function and tissue accumulation is one of degree (see also Coskun et al. 2019c). Coskun et al. (2019c) recently described yet another exception in the case of NsLsil from tobacco, in which it possessed both a GSGR selectivity filter and 108 aa spanning the NPA domains, and yet displayed little $\mathrm{Si}$ permeability, matching the low-Si phenotype in planta. Here, a single aa substitution to a highly conserved residue found in Si-permeable homologs (i.e., P125F) resulted in a gain of function that coincided with increased plasma-membrane localization of the protein. A very similar scenario was also described for a Lsi1 variant from pumpkin (Mitani et al. 2011). 
Taken together, these findings demonstrate a highly detailed and continuously developing description of the structure-function and genotype-phenotype relationships related to Lsi1, proving to be instrumental in understanding why species can and cannot accumulate Si (Coskun et al. 2019a, b; Deshmukh et al. 2020). However, as we shall describe next, this level of understanding does not currently apply to Lsi2.

\section{Lsi2: The black box}

\section{Background}

As with the discovery of OsLsil, OsLsi2 was identified by selecting a mutant rice plant that did not display deleterious symptoms when grown in the presence of germanium $(\mathrm{Ge})$, a toxic analog of Si (Ma et al. 2007). This mutant was also shown to accumulate lower quantities of Si than the WT counterpart and exhibited lower grain yield when grown in the field (presumably because of reduced stress resistance). Genome mapping led to the identification of a locus that included the gene for a putative anion transporter of unknown function but shared some homology with the prokaryotic arsenite (As(III)) transporter, ArsB (Meng et al. 2004). Complementation of the mutant with the OsLsi2 gene rescued the phenotype. Like OsLsil, OsLsi2 expression was shown to be downregulated in response to prolonged Si supplementation (Table 1). Moreover, OsLsi2 was found to localize within the plasma membrane at the proximal side of exodermal and endodermal cells (i.e., across from OsLsil in the same cell types). Heterologous expression of OsLsi2 in the Xenopus laevis oocyte system revealed some Si-efflux activity in preloaded cells, but no influx activity in the experimental setup chosen.

Based on these results, it was suggested that OsLsi2 acted as an efflux transporter, and in conjunction with OsLsi1, transported Si across the root and into the stele (Fig. 1; Ma et al. 2007; Ma and Yamaji 2015). Since then, homologs have been cloned and characterized from barley (Mitani et al. 2009b), maize (Mitani et al. 2009b), pumpkin (Mitani-Ueno et al. 2011), horsetail (Vivancos et al. 2016), soybean
(Bélanger et al. 2016), cucumber (Sun et al 2018), and tomato (Sun et al. 2020).

Phylogeny

A recent phylogenetic analysis of silicon transporters across the biological kingdoms found Lsi2 (or Lsi2like) genes present throughout the eukaryotic supergroups, including Amoeboza, Opisthokonts (metazoa, sponges, and choanoflagellates), Haptophytes, Alveolates, Rhizaria, Stramenopiles (diatoms, chrysophytes), and the Archaeplastida (embryophytes) (Marron et al. 2016). Given that $\mathrm{Si}(\mathrm{OH})_{4}$ autopolymerizes into $\mathrm{SiO}_{2}$ above concentrations of $c .2 \mathrm{mM}$ under most conditions (with the apparent exception of the xylem apoplast; see below; Belton et al. 2012) and free $\mathrm{SiO}_{2}$ in the cytoplasm is catastrophic for cellular metabolism (Iler 1979; Martin-Jézéquel et al. 2000; Montpetit et al. 2012), it has been proposed that siliceous organisms such as diatoms sequester $\mathrm{Si}$ within vesicles for controlled polymerization. Thus, Marron et al. (2016) proposed that the original function of Si-permeable transporters was as a detoxification mechanism to remove excess $\mathrm{Si}(\mathrm{OH})_{4}$ (or perhaps other toxic metalloids, such as $\mathrm{As}(\mathrm{OH})_{3}$ ) from the cytosol. Accordingly, Lsi2 may have had such a role very early in land plant evolution, even before the recruitment of NIP-III proteins (Lsi1) as passive Si channels some $500 \mathrm{Ma}$ (million years ago; Trembath-Reichert et al. 2015; Pommerrenig et al. 2020; Deshmukh et al. 2020).

Our own phylogenetic analysis of Lsi2 throughout the plant kingdom shows a high level of conservation throughout the embryophytes (bryophytes and tracheophytes) and presence even among the chlorophytes (green algae) (Fig. 2). Embryophytes are estimated to have evolved about 515 to $470 \mathrm{Ma}$ (Morris et al. 2018), and the presence of Lsi2 in primitive land plants indicates its early evolution. Interestingly, of the 37 embryophyte species studied, Lsi2 was absent in only one, the seagrass Zostera marina. In fact, $Z$. marina is known to have lost entire repertoires of genes, including stomatal genes, genes involved in terpenoid synthesis and ethylene signalling, as well as genes for ultraviolet protection and far-red-sensing phytochromes (Olsen et al. 2016); whether Lsi2 was similarly lost remains speculative. Likewise, it would appear 
Fig. 2 Taxonomical distribution of genomesequenced plant species obtained from the PLAZA 4.5 database (Van Bel et al. 2018). Numbers in parentheses denote the number of Lsi2 homologs identified in each species (sequences provided in Supplementary Table S4

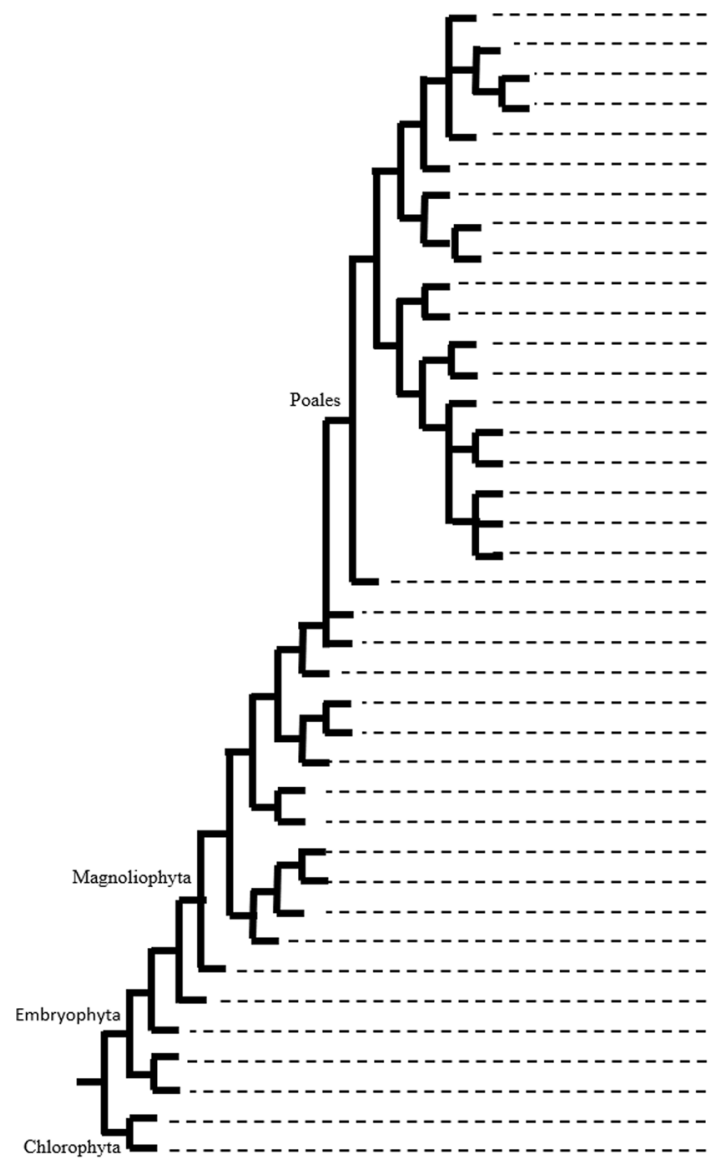

(5) Brachypodium distachyon

(10) Hordeum vulgare

(25) Triticum turgidum

(41) Triticum aestivum

(5) Lolium perenne

(5) Phyllostachys edulis

(6) Oryza brachyantha

(5) Oryza sativa ssp. japonica

(5) Oryza sativa ssp. indica

(6) Oropetium thomaeum

(9) Zoysia japonica ssp. nagirizaki

(5) Setaria italica

(5) Cenchrus americanus

(5) Sorghum bicolor

(14) Saccharum spontaneum

(11) Miscanthus sinensis

(6) Zea mays var. B73

(8) Zea mays var. $\mathrm{PH} 207$

(7) Zea mays var. B104

(4) Ananas comosus

(11) Calamus simplicifolius

(7) Musa acuminata

(8) Elaeis guineensis

(8) Phalaenopsis equestris

(5) Apostasia shenzhenica

(1) Asparagus officinalis

(1) Spirodela polyrhiza

(0) Zostera marina

(1) Arabidopsis thatiana

(9) Populus trichocarpa

(3) Vitis vinifera

(2) Solamum lycopersicum

(5) Amborella trichopoda

(3) Picea abies

(6) Selaginella moellendorffii

(1) Marchantia polymorpha

(3) Physcomitrella patens

(0) Chlamydomonas reinhardtii

(1) Micromonas commoda that Lsi2 is absent from the genome of the chlorophyte Chlamydomonas reinhardtii (Fig. 2).

A thorough phylogenetic analysis was further conducted on the Lsi2 homologs identified in Fig. 2, with the addition of those found in three other species (cucumber, pumpkin, and horsetail, which were not identified in the original genome database consulted for Fig. 2 but were included based on literature precedence; see 'Background' subsection, above). Thus, the tree was generated using 176 sequences that included all seven functionally characterized Lsi2s (Fig. 3). We found the sequences clustered into three major clades (denoted in black, blue, and red, and containing 4, 85, and 87 sequences, respectively). All functionally characterized Lsi2s grouped under a single clade (highlighted in blue; Fig. 3), indicating the higher sequence similarity among them. Moreover, these results highlight both the potential complexity and diversity of Lsi 2 transporters and our limited knowledge of their properties and functionality and how they relate within and among clades.

Protein structure

As Ma et al. (2007) first described, OsLsi2 consists of a 472-residue protein that is predicted to form 11 transmembrane domains flanked by an intracellular $\mathrm{N}$-terminus and extracellular C-terminus (Fig. 4). As it stands, no crystal structures of Lsi2 proteins have been reported. However, a homology-based structural prediction reveals the bacterial $\mathrm{Na}^{+}$-dependent citrate transporter, NaCT (also known as SLC13A5; PDB ID: 4F35; Mancusso et al. 2012), to share 99.5\% structural similarity with OsLsi2, albeit with very low sequence identity (17\% overall; Supplementary Fig. S1) and $23.4 \%$ in 184 overlapping residues (Supplementary Table S1). Based on structural similarity, one could speculate that Lsi2 can transport $\mathrm{Na}^{+}$and/ or tricarboxylates such as citrate and dicarboxylates 


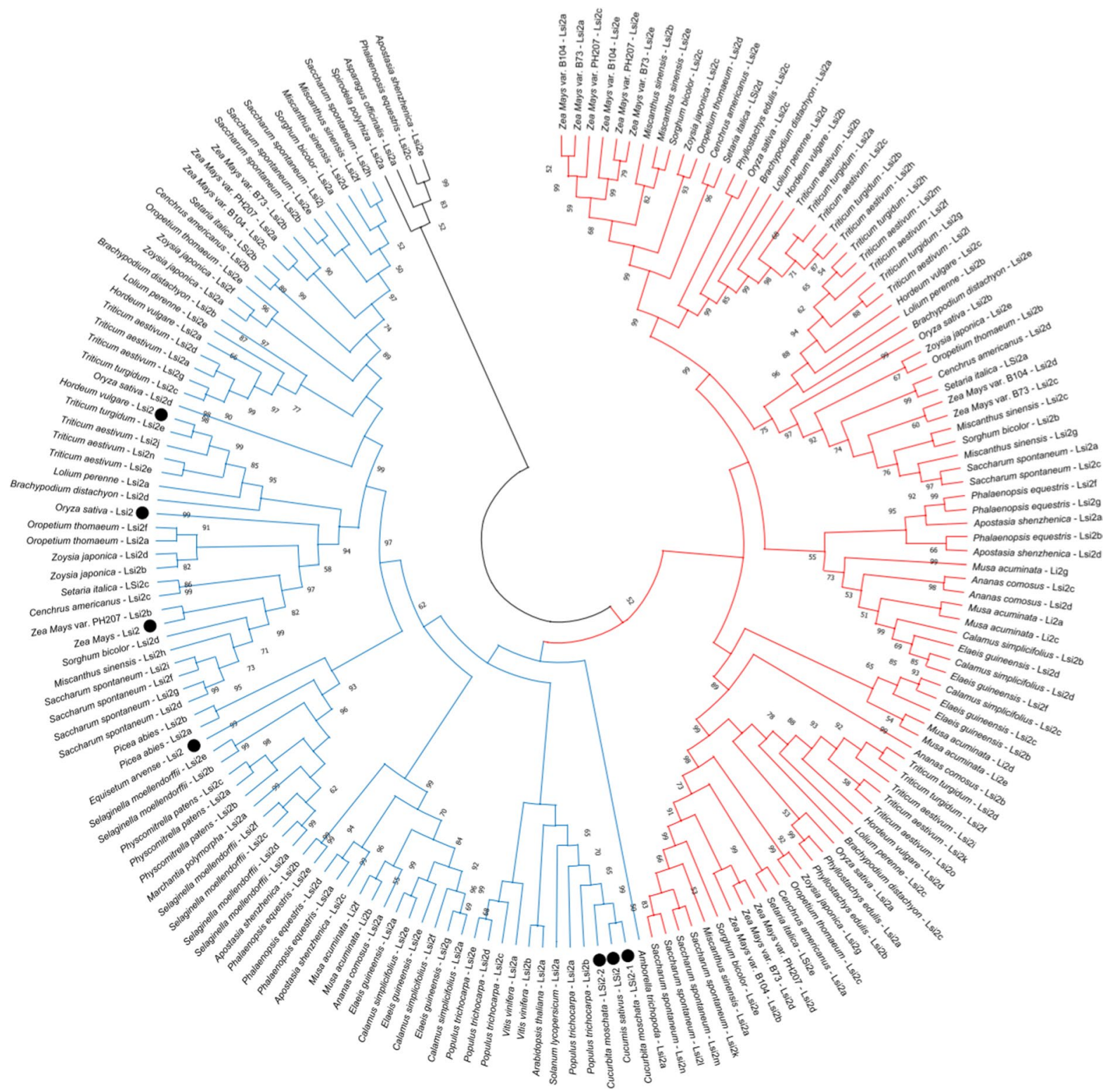

Fig. 3 Phylogenetic distribution of Lsi2 homologs identified in Fig. 2, as well as those found in the species Cucumis sativus, Cucurbita moschata, and Equisetum arvense (which were not available in the PLAZA 4.5 database). To date, only seven sequences have been functionally characterized for Si transport (as denoted by the black circles; see text for details). The tree

such as succinate, malate, and fumarate (Mancusso et al. 2012). In this regard, in-silico analysis indeed predicts citrate as the highest probability ligand for OsLsi2 (Supplementary Fig. S2). To our knowledge, no studies to date have investigated or reported transport of these potential substrates by Lsi2. was developed using the maximum-likelihood method provided in MEGA 7. Only proteins $>400$ amino acids were considered in the analysis. Sequences fell into three distinct clades, highlighted by blue, red, and black branches. Gene identifications can be found in Supplementary Table S3 and sequences are provided in Supplementary Table S4

Protein sequence alignment studies of six Lsi2s that have, to date, been functionally identified as $\mathrm{Si}$ permeable transporters in the Xenopus laevis oocyte system (i.e., OsLsi2, ZmLsi2, HvLsi2, CmLsi2-1, CsLsi2, and EaLsi2, from rice, maize, barley, pumpkin, cucumber, and horsetail, respectively) show a 


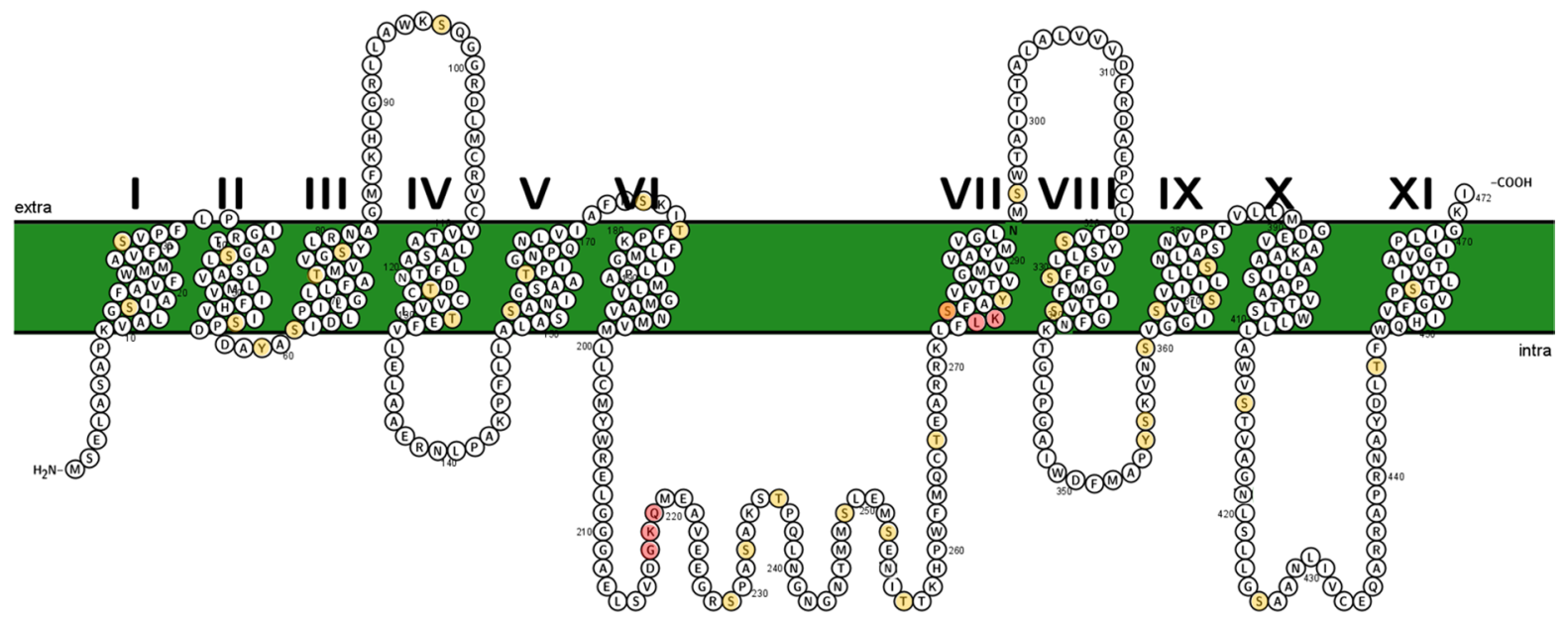

Fig. 4 Predicted secondary structure of OsLsi2 from rice (Oryza sativa). Transmembrane domains have been labeled in Roman numerals. Highlighted red, the residues that show similarity to the GXQ motifs thought to underlie the Si-selectivity of diatomic SIT transporters (Knight et al. 2016; see text for details; see also Supplementary Fig. S3). Note, no evidence currently exists to support their involvement in Lsi2-mediated Si transport. Highlighted yellow, residues predicted to be able to be phosphorylated; see Supplementary Fig. S4 for details). Structure prediction based on the SOSUI algorithm (http:// harrier.nagahama-i-bio.ac.jp/sosui/sosui_submit.html)

et al. (1997). The SITs are ubiquitous among the diatoms and are upregulated during silicification and in response to $\mathrm{Si}(\mathrm{OH})_{4}$ limitation (see Shrestha and Hildebrand 2015, and references therein). Saturable $\mathrm{Si}(\mathrm{OH})_{4}$-transport kinetics via SITs have been demonstrated in isolated diatom membrane vesicles, Xenopus laevis oocytes, and reconstituted proteoliposomes, and have been shown to be dependent on the transmembrane electrochemical $\mathrm{Na}^{+}$gradient (in a symport mechanism), likely in a $1: 1 \mathrm{Na}^{+} / \mathrm{Si}(\mathrm{OH})_{4}$ stoichiometry (see Knight et al. 2016, and references therein).

Like SLC13A5 and SLC34A2, very little similarity exists between SITs and Lsi2s, with only $23.5 \%$ sequence similarity in 34 overlapping residues between OsLsi2 and PtSIT1 from Phaeodactylum tricornutum (Supplementary Table S1). A key feature thought to be integral to $\mathrm{Si}(\mathrm{OH})_{4}$ binding in SITs is four highly conserved GXQ motifs that occur in pairs at the cytoplasmic ends of TM 2 and 3 and the extracellular ends of TM 7 and 8 (Knight et al. 2016). Interestingly, sequence alignment with OsLsi2 reveals the latter to indeed share the first GXQ motif (albeit within the TM 6-7 loop; i.e., GKQ at positions 218-220), some structural similarity with the second motif (LKS at positions 274-276), but no overlap with the second GXQ pair (Fig. 4; Supplementary Fig. S3). 
Fig. 5 Sequence alignment of six Lsi2 proteins (OsLsi2, ZmLsi2, HvLsi2, CmLsi2-1, CsLsi2, and EaLsi2, from rice (Oryza sativa), maize (Zea mays), barley (Hordeum vulgare), pumpkin (Curcurbita moschata), cucumber (Cucumis sativus), and horsetail (Equisetum arvense), respectively) that have, to date, been functionally verified to transport $\mathrm{Si}$ (in the Xenopus oocyte system; see text for details). In red, the 11 predicted transmembrane (TM) domains
TM1

TM2

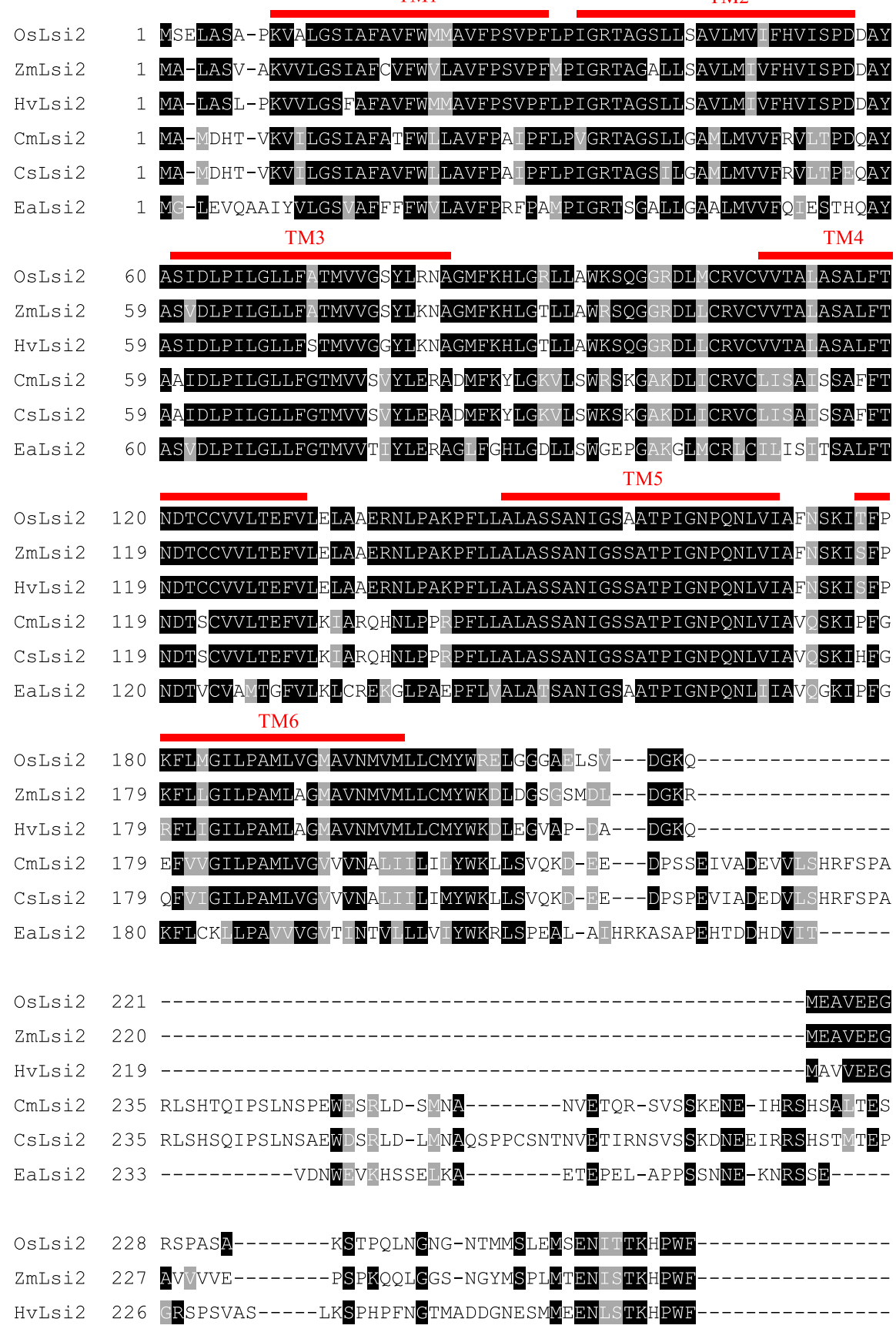

Further studies are needed to determine if these motifs are indeed involved in the Si-selectivity of Lsi2.

Lastly, an in-silico analysis predicting potential residues for phosphorylation (a key post-translational regulatory mechanism) identified 38 amino acids of interest for OsLsi2 (Fig. 4; Supplementary Fig. S4). Whether these residues are involved in protein phosphorylation and Lsi2 function remain to be evaluated.

Protein function

Aside from studies investigating the responses to genetic modifications in planta (e.g., Lsi2 knock-down, 
Fig. 5 (continued)

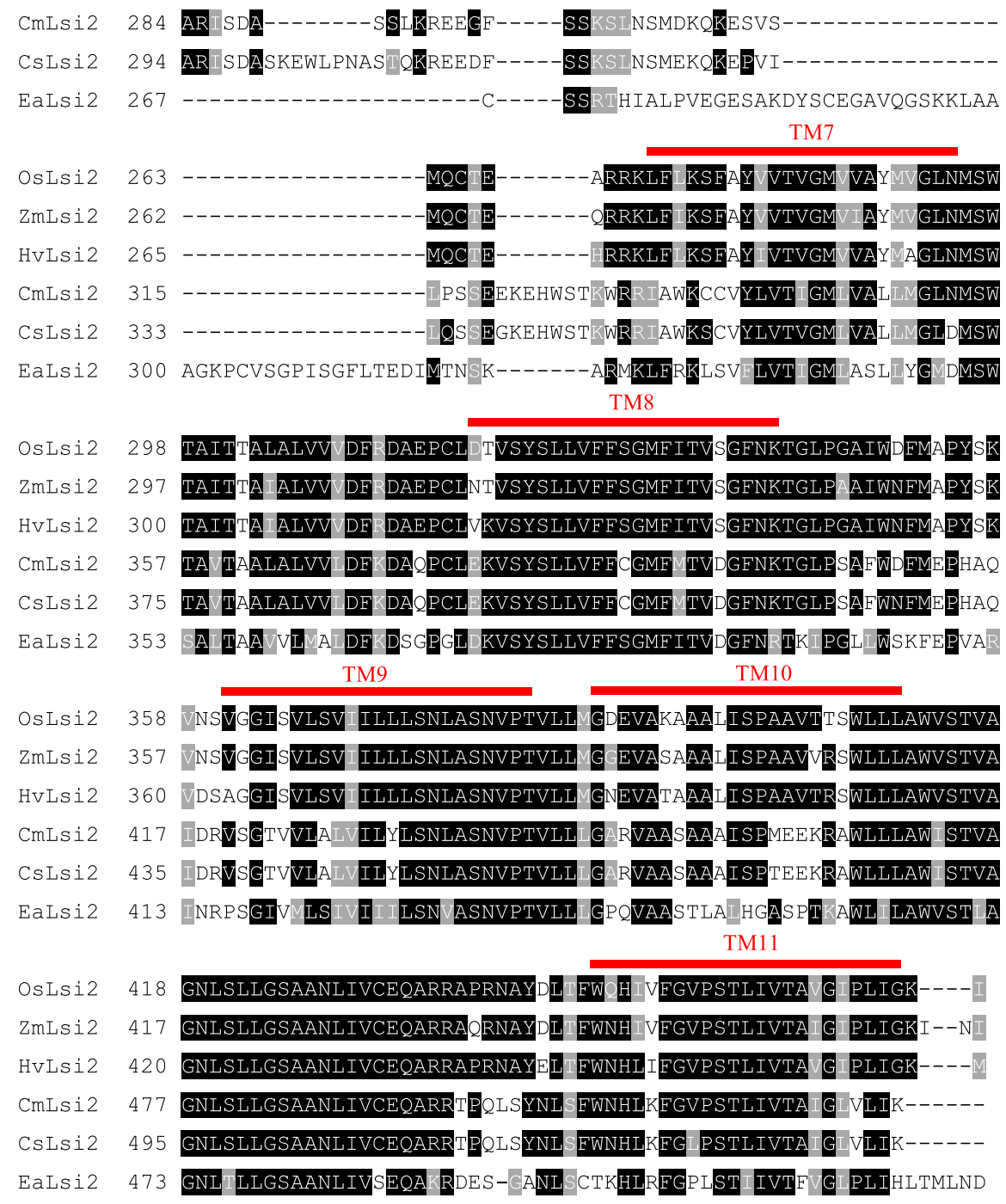

knock-out, or over-expression; Ma et al. 2007; Mitani et al. 2009b), to the best of our knowledge, the function of Lsi2 and its transport characteristics have thus far only been investigated in the Xenopus laevis oocyte expression system. Ma et al. (2007) first demonstrated Lsi2-mediated Si efflux after manually injecting Lsi2expressing oocytes with a ${ }^{68} \mathrm{Ge}$-labelled $\mathrm{Si}(\mathrm{OH})_{4}$ solution and monitoring the release of the radioisotope into a Si-/Ge-free medium over several hours. Using this method, they measured an efflux activity of $c .1 \mathrm{pmol}$ oocyte $^{-1} \mathrm{~h}^{-1}$. They also demonstrated the flux to be $\mathrm{pH}$-sensitive (decreasing with external alkalinity), temperature-sensitive $\left(c .80 \%\right.$ reduction at $10{ }^{\circ} \mathrm{C}$ relative to $18^{\circ} \mathrm{C}$ ), and inhibited by the protonophores DNP, CCCP, and FCCP (c. $20-40 \%$ reduction from controls).
These observations led the authors to propose a secondary active $\mathrm{Si}(\mathrm{OH})_{4} / \mathrm{H}^{+}$antiport mechanism (Fig. 1). Indeed, this may be intuitive, as secondary active transport in higher plants is predominately energized by $\mathrm{H}^{+}$gradients (Pedersen and Palmgren 2017), as opposed to $\mathrm{Na}^{+}$gradients (Sze et al. 1999; Mulkidjanian et al. 2008), which could explain the lack of $\mathrm{Na}^{+}$-powered SITs in this lineage (Marron et al. 2016). Since Ma et al. (2007), however, only a handful of studies have repeated these experiments, demonstrating Lsi2-mediated efflux for maize (Mitani et al. 2009b), barley (Mitani et al. 2009b), horsetail (Vivancos et al. 2016), and cucumber (Sun et al. 2018). Sun et al. (2020) studied SILsi2 from tomato and concluded it was Si-impermeable. It is worth 


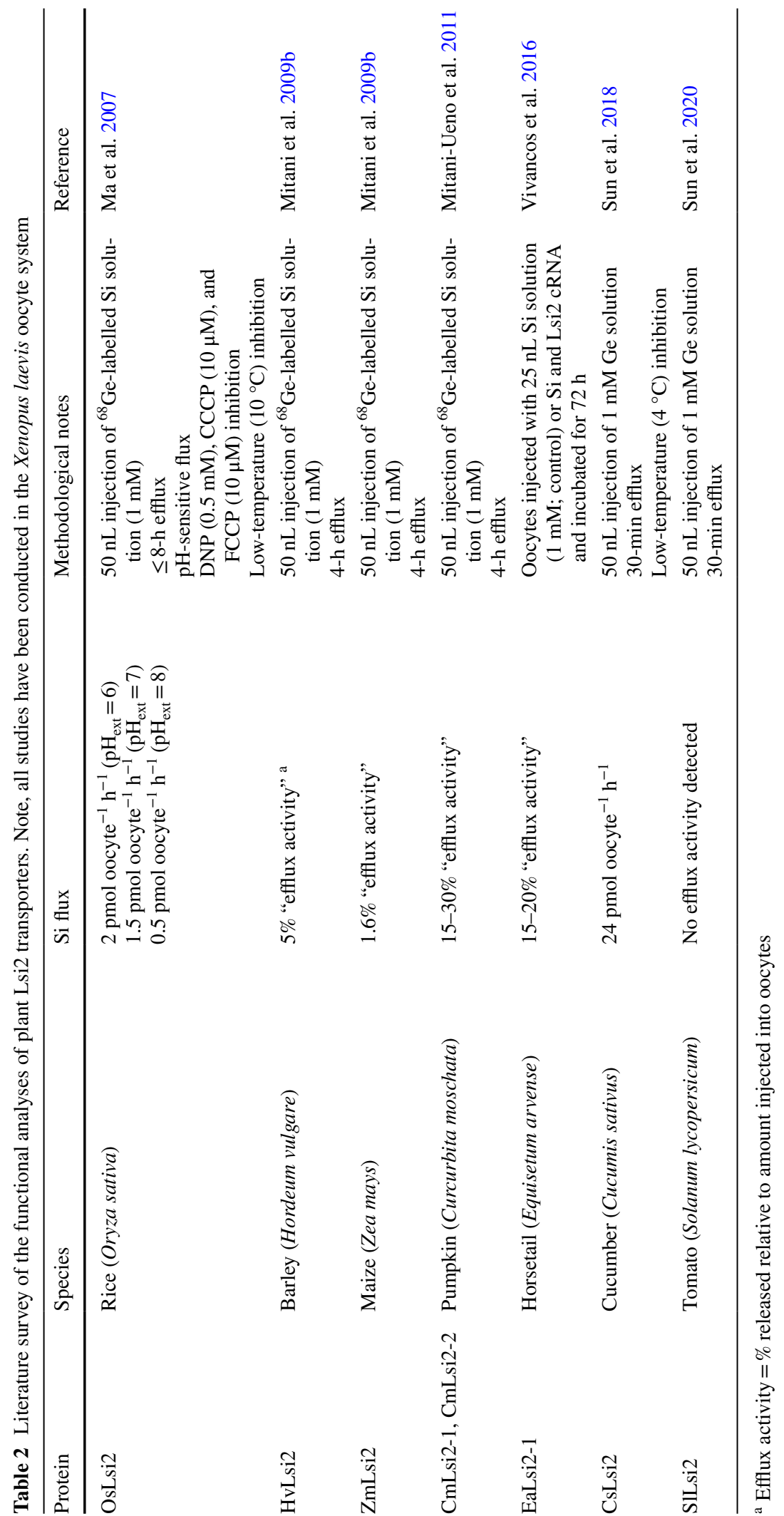


noting that, of all these studies, only Sun et al. (2018) repeated the temperature-sensitivity test described above. Otherwise, it would appear no other studies have conducted the system tests of Ma et al. (2007) (Table 2).

Although the studies described above have provided useful basic information on Lsi2 functionality, they also raise several critical issues:

(1) It remains disputable whether Ge (either as a stable or radioactive isotope) is a suitable proxy for $\mathrm{Si}$ in this system. Indeed, Ge has long been used as a proxy for studying $\mathrm{Si}$ in biological systems (Azam and Volcani 1981), including in SIT-expressing Xenopus oocytes (Hildebrand et al. 1997). Moreover, an absence of discrimination between ${ }^{68} \mathrm{Ge}$ and $\mathrm{Si}$ has been demonstrated in planta for several plant species (Nikolic et al. 2007). Nevertheless, it remains unclear if Ge fluxes reliably capture Si fluxes in Lsi2-expressing oocytes due to a lack of kinetic analyses and competition assays between the two substrates (see e.g., Hildebrand et al. 1997). Incidentally, methods for direct measurements of $\mathrm{Si}$ fluxes have been developed to a high degree of sensitivity and reproducibility (Deshmukh et al. 2015; Garneau et al. 2015; 2018; Vivancos et al. 2016; Coskun et al. 2019c), which should eliminate the need for analogs altogether, at least under nonsteady-state conditions such as described above, and provide a more reliable assessment of $\mathrm{Si}$ transport, contrary to arguments made by others (Sun et al. 2020).

(2) Manual injection of $\mathrm{Ge} / \mathrm{Si}$ into oocytes is a crude and potentially problematic procedure. For one, such non-steady-state conditions preclude an accurate appraisal of starting conditions for efflux assays. Wide variations in internal concentrations are inevitable across cells during the course of $\mathrm{Si} / \mathrm{Ge}$ injections and transfers to efflux solutions. It is also unclear what a bolus of Si (and a chemically "temperamental" one, at that; see 'Phylogeny' subsection, above) does to the internal biochemistry of the cell. Lastly, the conclusion that Lsi2s cannot mediate Si uptake in the oocyte system is perhaps premature, as it is based on less than 2-h uptake assays (see Fig. S11 in Ma et al. 2007; see also Sun et al. 2018; 2020). Whether Lsi2-expressing oocytes could indeed be capable of Si uptake given sufficient time should be further investigated.

(3) In its current application, the bioassay generates a flux occurring down a concentration gradient, i.e., a thermodynamically passive flux (one of facilitated diffusion). Although this does not necessarily preclude the possibility of a (secondary) active transport mechanism (i.e., an energydependent flux against a(n) (electro)chemical gradient), as the standing model suggests, this has yet to be experimentally demonstrated.

(4) The $\mathrm{Si}(\mathrm{OH})_{4} / \mathrm{H}^{+}$antiport model has also not been directly demonstrated (Ma and Yamaji 2008) (nor has an $\mathrm{As}(\mathrm{OH})_{3} / \mathrm{H}^{+}$antiport model, for that matter; Lindsay and Maathuis 2017), as no electrophysiological analyses have been carried out to show that Lsi2 is electrogenic and no $\mathrm{pH}$ measurements have been conducted to show that protons are indeed transported in exchange for $\mathrm{Si}$. The observed effects on $\mathrm{Si}$ efflux to changing external $\mathrm{pH}$ or the addition of protonophores could have alternative interpretations other than a transport site for protons. For instance, conformational changes to Lsi2 could occur in response to changes in extracellular $\mathrm{pH}$ (e.g., via protonation of histidine residues, etc.). Moreover, protonophores can dissipate the $\Delta \mathrm{pH}$ of a multitude of cellular compartments, including the mitochondrial proton gradient to uncouple respiration. It is also worth noting that, indeed, passive fluxes are also (indirectly) energy-dependent, requiring ATPases to generate the electrochemical gradients that drive these fluxes; thus, pharmacological manipulations of energy gradients do not necessarily and selectively target active-transport mechanisms.

(5) Basic kinetic analyses of the Lsi2-mediated $\mathrm{Si}$ flux are currently lacking. Although a time course of efflux was performed in OsLsi2-expressing oocytes (see above; Ma et al. 2007), questions pertaining to substrate affinity $\left(\mathrm{K}_{\mathrm{M}}\right)$ and velocity $\left(\mathrm{V}_{\max }\right)$ of the flux remain unaddressed, as are issues surrounding substrate competition (either direct or indirect; again, see above regarding $\mathrm{Ge}$ as a proxy).

Despite these shortcomings, it is nonetheless abundantly clear that Lsi2 is capable of mediating transmembrane $\mathrm{Si}$ fluxes. However, improvements are 
needed to develop a more elaborate and robust model considering some of the inconsistencies listed above. In this context, we discuss and propose approaches aimed at refining and building upon these important findings (see 'Future directions, hypotheses, and recommendations', below).

\section{Protein localization}

As Table 1 demonstrates, and unlike Lsi1 that exhibits variable cellular localization patterns across species (spanning epidermis to endodermis), Lsi2 appears confined to the endodermis, at least in the species investigated in the limited number of studies to date. In rice, OsLsi 2 is further confined to the proximal (i.e., inward-facing) side of endodermal cells (Ma et al. 2007), whereas in barley, maize, and cucumber, Lsi2 appears to show no polar localization (Mitani et al. 2009b; Sun et al. 2018; MitaniUeno and Ma 2020). Unfortunately, our understanding of Lsi2 localization in plants is confined to those species.

These observations have led some to suggest that the 'coordinated system' of OsLsi1 and OsLsi2 (i.e., polar localization of the transporters specifically in exo- and endo-dermal cells) may be unique to rice and explain its higher tissue $\mathrm{Si}$ content relative to most other species (Ma and Yamaji 2015; MitaniUeno and Ma 2020; it is also worth noting that polar localization of transporters also exist for other substrates, such as B, Fe, and auxin; Takano et al. 2010; Barberon et al. 2014; Raggi et al. 2020). It may, however, be premature to draw such conclusions. For one, the typical field conditions for rice (i.e., paddy soils and tropical climate) may be more conducive to soils with higher plant-available Si. Moreover, rice appears to accumulate $\mathrm{Si}$ to a very similar extent (when grown under identical conditions) to some species that lack this 'coordinated system' or have yet to be characterized as such. For example, Deshmukh et al. (2020) found 'crookneck pumpkin' (Cucurbita moschata) to accumulate 3.9\% leaf $\mathrm{Si}$ (and concentrations up to 5\% have been reported; Seki and Hotta 1997), contradicting the "passive"/ "intermediate" accumulator designation attributed to this species (Mitani-Ueno and Ma 2020); this despite CmLsi1 being present in all root cell types and without polar localization (Mitani et al. 2011). By contrast, cucumber has been reported to accumulate only $0.15-0.20 \% \mathrm{Si}$ in leaves, despite
CsLsi1 being polarly localized at the endodermis (Sun et al. 2017). Lastly, the sunflower species Helianthus petiolaris ('prairie sunflower'; $4.8 \%$ leaf $\mathrm{Si}$ ) and Helianthus exilis ('serpentine sunflower'; 5.2\% leaf $\mathrm{Si}$ ) accumulated more $\mathrm{Si}$ than rice (4.7\% leaf $\mathrm{Si}$ ) in controlled experiments (Deshmukh et al. 2020) - the expression/localization pattern of their Si transporters have yet to be determined.

Physiology

Early physiological studies of Si transport in roots from intact plants have shown that long-term steadystate $\mathrm{Si}$ uptake (i.e., net flux) can typically range between $1-10 \mu \mathrm{mol} g$ (root fresh weight) ${ }^{-1} \mathrm{~h}^{-1}$ (as measured by Si depletion of hydroponic media; Tamai and Ma 2003; Liang et al. 2005; Rains et al. 2006). These rates are indeed consistent with those observed for many mineral nutrients, including calcium $\left(\mathrm{Ca}^{2+}\right.$; Huang et al. 1992), nitrate $\left(\mathrm{NO}_{3}{ }^{-}\right.$; Kronzucker et al. 1999), and potassium ( $\mathrm{K}^{+}$; Coskun et al. 2016).

What remains to be determined, however, are the rates of the unidirectional fluxes of Si (i.e., influx and efflux, separately) and their direction (e.g., towards the xylem apoplast or the rhizosphere), as well as cellular pool sizes (i.e., Si concentration/activity in intracellular compartments, particularly the cytosol and vacuole). The absence of data in these regards may be attributable to methodological constraints, particularly in vivo, such as the unavailability and/or prohibitive cost of $\mathrm{Si}$ selective measurements including long-lived $\mathrm{Si}$ radiotracers (e.g., ${ }^{31} \mathrm{Si}\left[\mathrm{t}_{1 / 2}=2.6 \mathrm{~h}\right]$ or ${ }^{32} \mathrm{Si}\left[\mathrm{t}_{1 / 2} \approx 150 \mathrm{y}\right]$ ) and $\mathrm{Si}$-sensitive microelectrodes or fluorescent dyes.

Another question the 'coordinated' model raises is how does Si transport proceed from the endodermis to the xylem apoplast: are there unknown Si transporters in pericycle and xylem parenchyma cells, or are we to assume that Si simply travels apoplastically throughout the stele and into the xylem apoplast (see subsection 'Lsi2 is responsible for xylem loading and tissue Si content', below)? Within the xylem vessels, NMR analyses have reported $\mathrm{Si}$ concentrations up to $8 \mathrm{mM}$ (the vast majority as $\mathrm{Si}(\mathrm{OH})_{4}$; Casey et al. 2003; Liang et al. 2005) and as high as $20 \mathrm{mM}$ using calorimetric methods (Mitani and Ma 2005; Nikolic et al. 2007). If such concentrations are indeed representative of xylem Si concentrations in higher plants, they would certainly be consistent with some sort of 
active transport mechanism to pump $\mathrm{Si}$ against what must be a steep uphill concentration gradient.

\section{Future directions, hypotheses, and recommendations}

The previous section summarized the current state of understanding surrounding Lsi2 with respect to its phylogeny, protein structure and function, and physiological link to Si transport in planta. We also highlighted where deficiencies may lie in the standing model. Here, we attempt to provide some direction for addressing these gaps in knowledge, which we have organized around three major hypotheses: (1) Lsi2 expression is regulated by $\mathrm{Si},(2) \mathrm{Lsi} 2$ is a secondary active $\mathrm{Si}(\mathrm{OH})_{4} / \mathrm{H}^{+}$antiporter, and (3) Lsi2 is responsible for xylem Si loading and thus dictates shoot Si content.

Lsi2 expression is regulated by $\mathrm{Si}$

As Table 1 shows, there is no consensus on how the expression of Lsi2 (or Lsil for that matter) responds to Si supply. We see contradictory results between studies even within the same species (rice). Indeed, while Ma et al. (2007) showed strong downregulation of OsLsi2 expression after 3-d Si supply (see also Yamaji and Ma 2011; Mitani-Ueno et al. 2016), Kim et al. (2014) showed a 2- to four-fold increase after just 1-d Si supply. In both studies, external Si was set at a concentration of $1 \mathrm{mM}$, but the japonica cultivars tested were not the same. In maize and barley, Lsi2 expression was downregulated with Si supply (Mitani et al. 2009b), whereas cucumber Lsi2 was upregulated (Sun et al. 2018).

Mitani-Ueno et al. (2016) provide an excellent example of how future investigations into Lsil and Lsi2 gene expression responses ought to be conducted. The authors presented a convincing case that OsLsil and OsLsi2 expression in rice roots was negatively regulated by shoot $\mathrm{Si}$ specifically. Not only did they demonstrate a strong negative correlation between root gene expression and shoot Si content by carefully conducting a dose- and time-dependent growth experiment in WT seedlings, they showed that the loss-of-function oslsil mutant, which accumulated marginal $\mathrm{Si}$ in its shoots $(0.4 \%$ versus $6.1 \%$ in WT), did not alter its root expression of OsLsil and OsLsi2; interestingly, OsLsi 1 and OsLsi2 expression was not different between mutant and WT when plants were Si-deplete. A split-root $( \pm \mathrm{Si})$ experiment revealed that even roots without $\mathrm{Si}$ supplementation showed downregulation of OsLsil and OsLsi2, further buttressing the hypothesis that a shoot-derived signal was directing gene expression in the roots. Lastly, the authors determined that a specific region of the OsLsil promoter is linked to the gene-expression response; whether this is similarly the case for OsLsi2 should be investigated.

Whether Lsi2 is regulated at the transcriptional, translational, and/or posttranslational level (e.g., via transcription factors, regulatory proteins, miRNAs, or protein phosphorylation) remains largely unaddressed to date. Recently, a R2R3 MYB transcription factor, OsARM1, was found to negatively regulate genes linked to As(III) transport, including OsLsil and OsLsi2, by interacting with the promoter regions and thus regulating the uptake and root-to-shoot translocation of As(III) (Wang et al. 2017). Knocking out OsARM1 resulted in enhanced As(III) translocation; overexpression resulted in the opposite response. Presumably OsARM1 would similarly regulate $\mathrm{Si}$ transport and accumulation; however, this has yet to be demonstrated. Indeed, a vast literature on the regulation of As(III) transport exists, which one could draw upon for research direction (see e.g., Tang and Zhao 2020, and references therein). This includes the involvement of the soluble N-ethylmaleimide-sensitive factor attachment protein receptor (SNARE) protein AtSYP51 in regulating membrane trafficking of AtNIP1;1 (Barozzi et al. 2018), the $\mathrm{Ca}^{2+}$-dependent protein kinase AtCPK31 positively regulating As(III) uptake via AtNIP1;1 (Ji et al. 2017), and protein phosphorylation regulating polar localization and endocytosis of AtNIP5;1 (Wang et al. 2017).

It has also been demonstrated that water-deficit stress in general and abscisic acid (ABA) specifically (the phytohormone which accumulates in response to water deficit) can rapidly (within hours) result in downregulation of OsLsil and OsLsi2 expression and reduce Si uptake (Ma et al. 2006; Yamaji and Ma 2007; 2011). It has been suggested that ABA could directly downregulate OsLsil and OsLsi2 expression since the promoter regions of both genes display putative ABA-responsive cis-regulatory elements (Yamaji and Ma 2007; 2011); direct evidence of interaction is however forthcoming. Perplexingly, OsLsil 
expression was shown to be strongly upregulated in rice roots in response to salinity stress $(50 \mathrm{mM} \mathrm{NaCl}$ for $12 \mathrm{~d}$; Senadheera et al. 2009), despite ABA known to accumulate in response to salinity stress, much like with water deficit (Osakabe et al. 2014). Although it remains unclear how to reconcile these reports, the question of Lsil and Lsi2 gene expression in response to stress is clearly in need of elucidation.

Lsi2 is a secondary active $\mathrm{Si}(\mathrm{OH})_{4} / \mathrm{H}^{+}$antiporter

As outlined in the previous section, much more evidence is required to buttress the widely held model of $\mathrm{Si}(\mathrm{OH})_{4} / \mathrm{H}^{+}$antiport. Firstly, it is imperative that the concomitant flux be demonstrated, i.e., the $\mathrm{H}^{+}$flux $(\Delta \mathrm{pH})$ and its Si-dependence. This can be achieved, for example, by means of $\mathrm{pH}$-sensitive microelectrodes or fluorescent dyes. For instance, $\mathrm{pH}$-sensitive microelectrodes have been routinely used to measure intra- and extra-cellular $\mathrm{pH}$ changes in response to fluxes of various substrates, particularly in the Xenopus oocyte system (Bröer et al. 1998; Nakhoul et al. 1998; Holm et al. 2005). Likewise, pH-sensitive fluorescent dyes have been traditionally employed to demonstrate $\mathrm{H}^{+}$/substrate antiport mechanisms. Using the fluorescence quenching method of $\mathrm{pH}$-sensitive probes such as quinacrine and acridine orange, typically in everted membrane vesicles or reconstituted proteoliposomes, the $\mathrm{Na}^{+} / \mathrm{H}^{+}$antiport mechanism of transporters such as SOS1 and NHX1 have been routinely characterized and instrumental in understanding plant $\mathrm{Na}^{+}$transport (Apse et al. 1999; Qui et al. 2002), and could help elucidate Lsi2 function. To test the model in vivo, genetically encoded ratiometric $\mathrm{pH}$ sensors (pHlourin or pHusion; Gjetting et al. 2012; Martinière et al. 2018) anchored to either side of the plasma membrane can be used to measure changes in apoplastic and cytosolic $\mathrm{pH}$ in response to $\mathrm{Si}$.

Other techniques could lend themselves to also further characterizing the Lsi2-mediated Si flux. For example, a novel fluorescent technique utilizing zinc salts to measure Si flux kinetics in SIT-expressing proteoliposomes could be employed to study Lsi2 in vitro (Knight et al. 2016). This technique could also be useful to test alternative hypotheses into whether other co-substrates for Si exist. For example, a suite of cation or anion additions or subtractions from the external media could be performed to test for the existence of other potential co-substrates.
It is also worth considering whether Lsi2 could be an accessory protein to a larger Si-transporter complex. For example, it has been demonstrated that although ArsB can catalyze As(III) efflux coupled to the electrochemical proton gradient, when it binds ArsA, it is converted into a primary ATP-coupled As(III) efflux pump (Garbinski et al. 2019). Alternatively, it could be that Lsi2 function is dependent on unknown cellular constituents which are currently absent in the heterologous expression assay. For example, the plant $\mathrm{K}^{+}$channel AKT1 was only observed to be functional in the Xenopus oocyte system once its corresponding protein kinase CIPK23 and $\mathrm{Ca}^{2+}$-binding calcineurin B-like proteins CBL1 and CBL9 were co-expressed (Xu et al. 2006). Phosphorylation predictions, such as presented in Fig. 4 (see also Supplementary Fig. S4), could help make inroads towards better understanding this process.

Lastly, we should keep open the possibility that anionic silicate (i.e., some level of deprotonated silicic acid) is the penetrating $\mathrm{Si}$ species, at least until such time as this is empirically ruled out. Given the relatively high $\mathrm{pKa}$ of $\mathrm{Si}(\mathrm{OH})_{4}$ (9.8), one might assume that the penetrating species at physiological $\mathrm{pH}$ is of the conjugate acid; however, this may not necessarily be the case. Lsi2 does share some homology with bacterial (poly)anion transporters (see 'Protein structure' subsection, above), and thus could potentially provide support for this alternative hypothesis. Moreover, it is worth noting that B efflux is thought to be mediated by BOR transporters in a borate $\left(\left[\mathrm{B}(\mathrm{OH})_{4}\right]^{-}\right) / \mathrm{H}^{+}$antiport mechanism (pKa of boric acid is 9.24; Miwa and Fujiwara 2010; Onuh and Miwa 2021). Similarly, sizable $\mathrm{NH}_{3}$ fluxes were detected in barley roots despite a $\mathrm{NH}_{3} / \mathrm{NH}_{4}{ }^{+}$pKa of 9.25 (Coskun et al. 2013).

Lsi2 is responsible for xylem loading and tissue $\mathrm{Si}$ content

As mentioned above, the question of how Si is transported between the endodermis and xylem apoplast remains elusive but is critical if we are to understand how $\mathrm{Si}$ translocation functions and is regulated. Are there $\mathrm{Si}$ transporters present in the pericycle and xylem parenchyma that have yet to be discovered, and if so, by what mechanism do they operate? Or are we to presume that Si simply and freely 
diffuses into the xylem apoplast once released by Lsi2 in the endodermis, as the standing model seems to suggest? One thing is clear, the relative dearth of immunolocalization studies for Lsi2 (see 'Protein localization' subsection, above) demonstrates the necessity for many more such analyses. Perhaps then one can get a clearer understanding of the extent of Lsi2 localization.

Once again, we might look to the As(III)-transport literature to shed some light. Indeed, OsLsi2 has been demonstrated to be capable of As(III) transport and a crucial component of the xylem-loading process (Ma et al. 2008), but other transporters have been identified in pericycle and xylem parenchyma cells, including a C-type ATP-binding cassette (ABC) transporter, OsABCC7, which plays a more direct role in xylem loading and root-to-shoot translocation of As(III) (Tang et al. 2019; Tang and Zhao 2020). It is still unknown if such mechanisms exist for $\mathrm{Si}$.

The fundamental role of Lsi2, and whether it evolved to transport $\mathrm{Si}$, or whether it served some other adaptive purpose(s), is also crucial to understand. The fact that Lsi2 is present in many non-siliceous higher plant species (e.g., throughout the Brassicaceae and Solanaceae; Fig. 2; Coskun et al. 2019a) suggests the latter. However, the question of functionality is crucial: much like with Lsil, until it is verified that the encoded protein is capable of transporting $\mathrm{Si}$, the relevance of the presence/absence of a gene is very limited. Indeed, these genes may have evolved as ancient detoxification mechanisms for substrates such as As(III) or essential micronutrients such as B, and only surreptitiously resulted in Si-derived benefits from also being Si-permeable (in some species).

\section{Conclusions}

A relative lack in the absolute number of studies (including in methodological variety) has left a void where the physiological roles and molecular mechanisms of Lsi2 remain obscure, particularly in comparison to Lsi1. Thus, there is a need for much more supportive evidence to the standing transport model and for additional studies to understand the characteristics of the Si transport cycle. Although it is reasonable to infer an active Si-efflux mechanism, given the passive nature of the influx system and the high concentrations of $\mathrm{Si}$ in the xylem and shoot tissues, as it stands, a cautious refrain from perpetuating the claim that Lsi2 is an "active Si transporter" is warranted, until such time as more substantive and direct evidence is presented.

The opportunity to exploit Lsi2 for breeding purposes exists (Bélanger et al. 2016). However, the roles played by this transporter in Si fluxes and the overall physiology of plants need to be elucidated, especially if we are to effectively exploit $\mathrm{Si}$ as a prophylactic agent against environmental stress. With increased researcher attention and hypothesis-driven experimentation, Lsi2 need not be a black box in plant $\mathrm{Si}$ transport for long.

Supplementary Information The online version contains supplementary material available at https://doi.org/10.1007/s11104021-05061-1.

Open Access This article is licensed under a Creative Commons Attribution 4.0 International License, which permits use, sharing, adaptation, distribution and reproduction in any medium or format, as long as you give appropriate credit to the original author(s) and the source, provide a link to the Creative Commons licence, and indicate if changes were made. The images or other third party material in this article are included in the article's Creative Commons licence, unless indicated otherwise in a credit line to the material. If material is not included in the article's Creative Commons licence and your intended use is not permitted by statutory regulation or exceeds the permitted use, you will need to obtain permission directly from the copyright holder. To view a copy of this licence, visit http://creativecommons.org/licenses/by/4.0/.

\section{References}

Apse MP, Aharon GS, Snedden WA, Blumwald E (1999) Salt tolerance conferred by overexpression of a vacuolar $\mathrm{Na}^{+} /$ $\mathrm{H}^{+}$antiport in Arabidopsis. Science 285:1256-1258. https://doi.org/10.1126/science.285.5431.1256

Azam F, Volcani BE (1981) Germanium-silicon interactions in biological systems. In: Simpson TL, Volcani BE (ed) Silicon and Siliceous Structures in Biological Systems. Springer-Verlag, New York, pp 43-67. https://doi.org/10.1007/978-1-4612-5944-2_3

Barberon M, Dubeaux G, Kolb C, Isono E, Zelazny E, Vert G (2014) Polarization of IRON-REGULATED TRANSPORTER 1 (IRT1) to the plant-soil interface plays crucial role in metal homeostasis. Proc Natl Acad Sci USA 111:8293-8298. https://doi.org/10.1073/pnas.14022 62111

Barozzi F, Papadia P, Stefano G, Renna L, Brandizzi F, Migoni D, Fanizzi FP, Piro G, Di Sansebastiano G-P (2018) Variation in membrane trafficking linked to SNARE AtSYP51 interaction with aquaporin NIP1;1. Front Plant Sci 9:1949. https://doi.org/10.3389/fpls.2018.01949 
Bélanger RR, Deshmukh R, Belzile F, Labbé C, Perumal A, Edwards SM (2016) Plant with increased silicon uptake. Patent No.: WO/2016/183684

Belton DJ, Deschaume O, Perry CC (2012) An overview of the fundamentals of the chemistry of silica with relevance to biosilicification and technological advances. FEBS J 279:1710-1720. https://doi.org/10.1111/j.1742-4658.2012. 08531.x

Bokor B, Bokorová S, Ondoš S et al (2015) Ionome and expression level of Si transporter genes (Lsi1, Lsi2, and LsiO) affected by $\mathrm{Zn}$ and $\mathrm{Si}$ interaction in maize. Environ Sci Poll Res 22:6800-6811. https://doi.org/10.1007/ s11356-014-3876-6

Bokor B, Soukup M, Vaculík M et al (2019) Silicon uptake and localisation in date palm (Phoenix dactylifera) - A unique association with sclerenchyma. Front Plant Sci 10:988. https://doi.org/10.3389/fpls.2019.00988

Bröer S, Schneider H-P, Bröer A, Rahman B, Hamprecht B, Deitmer JW (1998) Characterization of the monocarboxylate transporter 1 expressed in Xenopus laevis oocytes by changes in cytosolic pH. Biochem $\mathrm{J}$ 333:167-174. https://doi.org/10.1042/bj3330167

Carey JC, Fulweiler RW (2012) The Terrestrial Silica Pump PLOS ONE 7:e52932. https://doi.org/10.1371/journal.pone.00529 32

Casey WH, Kinrade SD, Knight CTG, Rains DW, Epstein E (2003) Aqueous silicate complexes in wheat, Triticum aestivum L. Plant Cell Environ 27:51-54. https://doi.org/ 10.1046/j.0016-8025.2003.01124.x

Chiba Y, Mitani N, Yamaji N, Ma JF (2009) HvLsi1 is a silicon influx transporter in barley. Plant Journal 57:810-818. https://doi.org/10.1111/j.1365-313X.2008.03728.x

Coskun D, Britto DT, Li M, Becker A, Kronzucker HJ (2013) Rapid ammonia gas transport accounts for futile transmembrane cycling under $\mathrm{NH}_{3} / \mathrm{NH}_{4}{ }^{+}$toxicity in plant roots. Plant Physiology 163:1859-1867. https://doi.org/ 10.1104/pp.113.225961

Coskun D, Britto DT, Kochian LV, Kronzucker HJ (2016) How high do ion fluxes go? A re-evaluation of the twomechanism model of $\mathrm{K}^{+}$transport in plant roots. Plant Sci 243:96-104. https://doi.org/10.1016/j.plantsci.2015. 12.003

Coskun D, Deshmukh RK, Sonah H et al (2019a) The controversies of silicon's role in plant biology. New Phytol 221:67-85. https://doi.org/10.1111/nph.15343

Coskun D, Deshmukh RK, Sonah H et al (2019b) In defence of the selective transport and role of silicon in plants. New Phytol 223:514-516

Coskun D, Deshmukh RK, Sonah H et al (2019c) Si permeability of a deficient Lsi1 aquaporin in tobacco can be enhanced through a conserved residue substitution. Plant Direct 3:e00163. https://doi.org/10.1002/pld3.163

Deshmukh RK, Vivancos J, Guérin V, Sonah H, Labbé C, Belzile F, Bélanger RR (2013) Identification and functional characterization of silicon transporters in soybean using comparative genomics of major intrinsic proteins in Arabidopsis and rice. Plant Molec Biol 83:303-315. https://doi.org/10.1007/s11103-013-0087-3

Deshmukh RK, Vivancos J, Ramakrishnan G et al (2015) A precise spacing between the NPA domains of aquaporins is essential for silicon permeability in plants. Plant $\mathrm{J}$ 83:489-500. https://doi.org/10.1111/tpj.12904

Deshmukh RK, Sonah H, Bélanger RR (2020) New evidence defining the evolutionary path of aquaporins regulating silicon uptake in land plants. J Exp Bot 71:6775-6788. https://doi.org/10.1093/jxb/eraa342

de Tombeur F, Turner BL, Laliberté E (2020) Plants sustain the terrestrial silicon cycle during ecosystem retrogression. Science 369:1245-1248. https://doi.org/10.1126/ science.abc0393

Epstein E (1994) The anomaly of silicon in plant biology. Proc Natl Acad Sci USA 91:11-17. https://doi.org/10. 1073/pnas.91.1.11

Epstein E (1999) Silicon Ann Rev Plant Phys 50:641-664. https://doi.org/10.1146/annurev.arplant.50.1.641

Garbinski LD, Rosen BP, Chen J (2019) Pathways of arsenic uptake and efflux. Environ Int 126:585-597. https://doi. org/10.1016/j.envint.2019.02.058

Garneau AP, Carpentier GA, Marcoux A-A et al (2015) Aquaporins mediate silicon transport in humans. PLoS One 10:e0136149. https://doi.org/10.1371/journal. pone. 0136149

Garneau AP, Marcoux A-A, Frenette-Cotton R, Bélanger RR, Isenring P (2018) A new gold standard approach to characterize the transport of $\mathrm{Si}$ across cell membranes in animals. J Cell Physiol 233:6369-6376. https://doi. org/10.1002/jcp.26476

Gjetting SK, Ytting CK, Schulz A, Fuglsang AT (2012) Live imaging of intra-and extracellular $\mathrm{pH}$ in plants using pHusion, a novel genetically encoded biosensor. J Exp Bot 63:3207-3218. https://doi.org/10.1093/jxb/ers040

Grégoire C, Rémus-Borel W, Vivancos J, Labbé C, Belzile F, Bélanger RR (2012) Discovery of a multigene family of aquaporin silicon transporters in the primitive plant Equisetum arvense. Plant J 72:320-330. https://doi.org/ 10.1111/j.1365-313X.2012.05082.x

Hildebrand M, Volcani BE, Gassmann W, Schroeder JI (1997) A gene family of silicon transporters. Nature 385:688-689. https://doi.org/10.1038/385688b0

Hodson MJ, White PJ, Mead A, Broadley MR (2005) Phylogenetic variation in the silicon composition of plants. Ann Bot 96:1027-1046. https://doi.org/10.1093/aob/ mci255

Holm LM, Jahn TP, Møller ALB et al (2005) $\mathrm{NH}_{3}$ and $\mathrm{NH}_{4}{ }^{+}$ permeability in aquaporin-expressing Xenopus oocytes. Pflügers Archiv 450:415-428. https://doi.org/10.1007/ s00424-005-1399-1

Hosseini SA, Maillard A, Hajirezaei MR et al (2017) Induction of barley silicon transporter HvLsil and HvLsi2, increased silicon concentration in the shoot and regulated starch and $\mathrm{ABA}$ homeostasis under osmotic stress and concomitant potassium deficiency. Front Plant Sci 8:1359. https://doi.org/10.3389/fpls.2017.01359

Hove RM, Bhave M (2011) Plant aquaporins with nonaqua functions: deciphering the signature sequences. Plant Mol Biol 75:413-430. https://doi.org/10.1007/ s11103-011-9737-5

Huang JW, Shaff JE, Grunes DL, Kochian LV (1992) Aluminum effects on calcium fluxes at the root apex of aluminum-tolerant and aluminum-sensitive wheat cultivars. 
Plant Physiol 98:230-237. https://doi.org/10.1104/pp. 98.1.230

Iler KR (1979) The chemistry of silica: solubility, polymerization, colloid and surface proteins, and biochemistry. Wiley Interscience, New York

Ji R, Zhou L, Liu J et al (2017) Calcium-dependent protein kinase CPK31 interacts with arsenic transporter AtNIP1;1 and regulates arsenite uptake in Arabidopsis thaliana. PLoS One 12:e0173681. https://doi.org/10. 1371/journal.pone.0173681

Kim YH, Khan AL, Kim DH et al (2014) Silicon mitigates heavy metal stress by regulating P-type heavy metal ATPases, Oryza sativa low silicon genes, and endogenous phytohormones. BMC Plant Biol 14:13. https://doi. org/10.1186/1471-2229-14-13

Knight MJ, Senior L, Nancolas B, Ratcliffe S, Curnow P (2016) Direct evidence of the molecular basis for biological silicon transport. Nature Comm 7:11926. https://doi. org/10.1038/ncomms11926

Kronzucker HJ, Siddiqi MY, Glass ADM, Kirk GJD (1999) Nitrate-ammonium synergism in rice. A subcellular flux analysis. Plant Physiol 119:1041-1045. https://doi.org/ 10.1104/pp.119.3.1041

Kumar S, Adiram-Filiba N, Blum S et al (2020) Siliplant1 protein precipitates silica in sorghum silica cells. J Exp Bot 71:6830-6843. https://doi.org/10.1093/jxb/eraa258

Liang Y, Si J, Römheld V (2005) Silicon uptake and transport is an active process in Cucumis sativus. New Phytol 167:797-804. https://doi.org/10.1111/j.1469-8137.2005. 01463.X

Liang Y, Nikolic M, Bélanger RR, Gong H, Song A (2015) Silicon in agriculture: from theory to practice. Springer, Dordrecht

Lindsay ER, Maathuis FJM (2017) New molecular mechanisms to reduce arsenic in crops. Trends Plant Sci 22:10161026. https://doi.org/10.1016/j.tplants.2017.09.015

Ma JF (2004) Role of silicon in enhancing the resistance of plants to biotic and abiotic stresses. Soil Sci Plant Nutr 50:11-18. https://doi.org/10.1080/00380768.2004.10408 447

Ma JF, Yamaji N (2008) Functions and transport of silicon in plants. Cell Mol Life Sci 65:3049-3057. https://doi.org/ 10.1007/s00018-008-7580-x

Ma JF, Yamaji N (2015) A cooperative system of silicon transport in plants. Trends Plant Sci 20:435-442. https://doi. org/10.1016/j.tplants.2015.04.007

Ma JF, Tamai K, Yamaji N et al (2006) A silicon transporter in rice. Nature 440:688-691. https://doi.org/10.1038/natur e04590

Ma JF, Yamaji N, Mitani N et al (2007) An efflux transporter of silicon in rice. Nature 448:209-212. https://doi.org/10. 1038/nature05964

Ma JF, Yamaji N, Mitani N et al (2008) Transporters of arsenite in rice and their role in arsenic accumulation in rice grain. Proc Natl Acad Sci USA 105:9931-9935. https:// doi.org/10.1073/pnas.0802361105

Mancusso R, Gregorio GG, Liu Q, Wang D-N (2012) Structure and mechanism of a bacterial sodium-dependent dicarboxylate transporter. Nature 491:622-626. https://doi.org/ 10.1038/nature11542
Marron AO, Ratcliffe R, Wheeler GL et al (2016) The evolution of silicon transport in eukaryotes. Mol Biol Evol 33:3226-3248. https://doi.org/10.1093/molbev/msw209

Martinière A, Gibrat R, Sentenac H, Dumont X, Gaillard I, Paris N (2018) Uncovering $\mathrm{pH}$ at both sides of the root plasma membrane interface using noninvasive imaging. Proc Natl Acad Sci USA 115:6488-6493. https://doi. org/10.1073/pnas.1721769115

Martin-Jézéquel V, Hildebrand M, Brzezinski MA (2000) Silicon metabolism in diatoms: implications for growth. J Phycol 36:821-840. https://doi.org/10.1046/j. 1529-8817.2000.00019.x

Meng Y-L, Liu Z, Rosen BP (2004) As(III) and Sb(III) uptake by GlpF and efflux by ArsB in Escherichia coli. J Biol Chem 279:18334-18341. https://doi.org/10. 1074/jbc.M400037200

Mitani N, Ma JF (2005) Uptake system of silicon in different plant species. J Exp Bot 50:1255-1261. https://doi.org/ 10.1093/jxb/eri121

Mitani N, Yamaji N, Ma JF (2009a) Identification of maize silicon influx transporters. Plant Cell Physiol 50:5-12. https://doi.org/10.1093/pcp/pcn110

Mitani N, Chiba Y, Yamaji N, Ma JF (2009b) Identification and characterization of maize and barley Lsi2-like silicon efflux transporters reveals a distinct silicon uptake system from that in rice. Plant Cell 21:2133-2142. https://doi.org/10.1105/tpc.109.067884

Mitani N, Yamaji N, Ago Y, Iwasaki K, Ma JF (2011) Isolation and functional characterization of an influx silicon transporter in two pumpkin cultivars contrasting in silicon accumulation. Plant J 66:231-240. https://doi.org/ 10.1111/j.1365-313X.2011.04483.x

Mitani-Ueno N, Ma JF (2020) Linking transport system of silicon with its accumulation in different plant species. Soil Sci Plant Nutr 67:10-17. https://doi.org/10.1080/ 00380768.2020.1845972

Mitani-Ueno N, Yamaji N, Zhao F-J, Ma JF (2011) The aromatic/arginine selectivity filter of NIP aquaporins plays a critical role in substrate selectivity for silicon, boron, and arsenic. J Exp Bot 62:4391-4398. https://doi.org/ $10.1093 / \mathrm{jxb} / \mathrm{err} 158$

Mitani-Ueno N, Yamaji N, Ma JF (2016) High silicon accumulation in the shoot is required for down-regulating the expression of $\mathrm{Si}$ transporter genes in rice. Plant Cell Physiol 57:2510-2518. https://doi.org/10.1093/ pcp/pcw163

Miwa K, Fujiwara T (2010) Boron transport in plants: co-ordinated regulation of transporters. Annals of Botany 105 (7):1103-1108

Montpetit J, Vivancos J, Mitani-Ueno N et al (2012) Cloning, functional characterization and heterologous expression of TaLsil, a wheat silicon transporter gene. Plant Mol Biol 79:35-46. https://doi.org/10.1007/ s11103-012-9892-3

Morris JL, Puttick MN, Clark JW, Edwards D, Kenrick P, Pressel S, Wellman CH,Yang Z, Schneider H, Donoghue PCJ (2018) The timescale of early land plant evolution. Proceedings of the National Academy of Sciences 115 (10):E2274-E2283

Mulkidjanian AY, Galperin MY, Makarova KS, Wolf YI, Koonin EV (2008) Evolutionary primacy of sodium 
bioenergetics. Biol Direct 3:13. https://doi.org/10.1186/ 1745-6150-3-13

Murata K, Mitsuoka K, Hirai T et al (2000) Structural determinants of water permeation through aquaporin-1. Nature 407:599-605. https://doi.org/10.1038/35036519

Nakhoul NL, Davis BA, Romero MF, Boron WF (1998) Effect of expressing the water channel aquaporin-1 on the $\mathrm{CO} 2$ permeability of Xenopus oocytes. Am J Physiol 274:C543-C548. https://doi.org/10.1152/ajpcell.1998. 274.2.C543

Nikolic M, Nikolic N, Liang Y, Kirkby EA, Römheld V (2007) Germanium-68 as an adequate tracer for silicon transport in plants. Characterization of silicon uptake in different crop species. Plant Physiol 143:495-503. https://doi.org/ 10.1104/pp.106.090845

Noronha H, Silva A, Mitani-Ueno N et al (2020) The grapevine NIP2; 1 aquaporin is a silicon channel. J Exp Bot 71:6789-6798. https://doi.org/10.1093/jxb/eraa294

Olsen JL, Rouzé P, Verhelst B et al (2016) The genome of the seagrass Zostera marina reveals angiosperm adaptation to the sea. Nature 530:331-335. https://doi.org/10.1038/ nature 16548

Onuh AF, Miwa K (2021) Regulation, diversity and evolution of boron transporters in plants. The Plant Cell. https:// doi.org/10.1093/pcp/pcab025

Osakabe Y, Yamaguchi-Shinozaki K, Shinozaki K, Tran LSP (2014) ABA control of plant macroelement membrane transport systems in response to water deficit and high salinity. New Phytol 202:35-49. https://doi.org/10.1111/ nph. 12613

Pedersen JT, Palmgren M (2017) Why do plants lack sodium pumps and would they benefit from having one? Funct Plant Biol 44:473-479. https://doi.org/10.1071/FP16422

Pommerrenig B, Diehn TA, Bienert GP (2015) Metalloido-porins: Essentiality of Nodulin 26-like intrinsic proteins in metalloid transport. Plant Sci 238:212-227. https://doi. org/10.1016/j.plantsci.2015.06.002

Pommerrenig B, Diehn TA, Bernhardt N et al (2020) Functional evolution of nodulin 26-like intrinsic proteins: from bacterial arsenic detoxification to plant nutrient transport. New Phytol 225:1383-1396. https://doi.org/10. 1111/nph.16217

Qui QS, Guo Y, Dietrich MA, Schumaker KS, Zhu J-K (2002) Regulation of SOS1, a plasma membrane $\mathrm{Na}^{+} / \mathrm{H}^{+}$ exchanger in Arabidopsis thaliana, by SOS2 and SOS3. Proc Natl Acad Sci USA 99:8436-8441. https://doi.org/ 10.1073/pnas.122224699

Raggi S, Demes E, Liu S, Verger S, Robert S (2020) Polar expedition: mechanisms for protein polar localization. Curr Opin Plant Biol 53:134-140. https://doi.org/10. 1016/j.pbi.2019.12.001

Rains DW, Epstein E, Zasoski RJ, Aslam M (2006) Active silicon uptake by wheat. Plant Soil 280:223-228. https://doi. org/10.1007/s11104-005-3082-x

Ratcliffe S, Jugdaohsingh R, Vivancos J et al (2017) Identification of a mammalian silicon transporter. Am J PhysiolCell Ph 312:C550-C561. https://doi.org/10.1152/ajpcell. 00219.2015

Raven JA (2003) Cycling silicon - the role of accumulation in plants. New Phytol 158:419-430. https://doi.org/10. 1046/j.1469-8137.2003.00778.x
Seki M, Hotta Y (1997) Effect of bloomless stock cultivar on the growth and mineral uptake of cucumber plants. Res Bull Aichi Agric Res Ctr 29:127-133

Senadheera P, Singh RK, Maathuis FJM (2009) Differentially expressed membrane transporters in rice roots may contribute to cultivar dependent salt tolerance. J Exp Bot 60:2553-2563. https://doi.org/10.1093/jxb/erp099

Shrestha RP, Hildebrand M (2015) Evidence for a regulatory role of diatom silicon transporters in cellular silicon responses. Eukaryot Cell 14:29-40. https://doi.org/10. 1128/EC.00209-14

Street-Perrott FA, Barker PA (2008) Biogenic silica: a neglected component of the coupled global continental biogeochemical cycles of carbon and silicon. Earth Surf Proc Land 33:1436-1457. https://doi.org/10.1002/esp. 1712

Struyf E, Smis A, Van Damme S, Meire P, Conley DJ (2009) The global biogeochemical silicon cycle. Silicon 1:207213. https://doi.org/10.1007/s12633-010-9035-x

Sun H, Guo J, Duan Y, Zhang T, Huo H, Gong H (2017) Isolation and functional characterization of CsLsi1, a silicon transporter gene in Cucumis sativus. Physiol Plant 159:201-214. https://doi.org/10.1111/ppl.12515

Sun H, Duan Y, Qi X, Zhang L, Huo H, Gong H (2018) Isolation and functional characterization of CsLsi2, a cucumber silicon efflux transporter gene. Ann Bot 122:641648. https://doi.org/10.1093/aob/mcy103

Sun H, Duan Y, Mitani-Ueno N et al (2020) Tomato roots have a functional silicon influx transporter but not a functional silicon efflux transporter. Plant Cell Environ 43:732-744. https://doi.org/10.1111/pce.13679

Sze H, Li X, Palmgren MG (1999) Energization of plant cell membranes by $\mathrm{H}^{+}$-pumping ATPases: Regulation and biosynthesis. Plant Cell 11:677-689. https://doi.org/10. 1105/tpc.11.4.677

Takano J, Tanaka M, Toyoda A et al (2010) Polar localization and degradation of Arabidopsis boron transporters through distinct trafficking pathways. Proc Natl Acad Sci USA 107:5220-5225. https://doi.org/10.1073/pnas. 0910744107

Tamai K, Ma JF (2003) Characterization of silicon uptake by rice roots. New Phytol 158:431-436. https://doi.org/10. 1046/j.1469-8137.2003.00773.x

Tan L, Fan X, Yan G et al (2021) Sequestration potential of phytolith occluded carbon in China's paddy rice (Oryza sativa L.) systems. Sci Total Environ 774:145696. https://doi.org/10.1016/j.scitotenv.2021.145696

Tang Z, Zhao FJ (2020) The roles of membrane transporters in arsenic uptake, translocation and detoxification in plants. Crit Rev Environ Sci Tec. https://doi.org/10.1080/10643 389.2020.1795053

Tang Z, Chen Y, Miller AJ, Zhao FJ (2019) The C-type ATPbinding cassette transporter OsABCC7 is involved in the root-to-shoot translocation of arsenic in rice. Plant Cell Physiol 60:1525-1535. https://doi.org/10.1093/pcp/ pcz054

Trembath-Reichert E, Wilson JP, McGlynn SE, Fischer WW (2015) Four hundred million years of silica biomineralization in land plants. Proc Natl Acad Sci USA 112:54495454. https://doi.org/10.1073/pnas.1500289112 
Van Bel M, Diels T, Vancaester E et al (2018) PLAZA 4.0: An integrative resource for functional, evolutionary and comparative plant genomics. Nucleic Acids Res 46:D1190-D1196. https://doi.org/10.1093/nar/gkx1002

Vivancos J, Deshmukh R, Grégoire C, Rémus-Borel W, Belzile F, Bélanger RR (2016) Identification and characterization of silicon efflux transporters in horsetail (Equisetum arvense). J Plant Physiol 200:82-89. https://doi.org/10. 1016/j.jplph.2016.06.011

Wang FZ, Chen MX, Yu LJ et al (2017) OsARM1, an R2R3 MYB transcription factor, is involved in regulation of the response to arsenic stress in rice. Front Plant Sci 8:1868. https://doi.org/10.3389/fpls.2017.01868
Xu J, Li HD, Chen LQ et al (2006) A protein kinase, interacting with two calcineurin B-like proteins, regulates $\mathrm{K}^{+}$ transporter AKT1 in Arabidopsis. Cell 125:1347-1360. https://doi.org/10.1016/j.cell.2006.06.011

Yamaji N, Ma JF (2007) Spatial distribution and temporal variation of the rice silicon transporter Lsi1. Plant Physiol 143:1306-1313. https://doi.org/10.1104/pp.106.093005

Yamaji N, Ma JF (2011) Further characterization of a rice silicon efflux transporter, Lsi2. Soil Sci Plant Nutr 57:259264. https://doi.org/10.1080/00380768.2011.565480

Publisher's note Springer Nature remains neutral with regard to jurisdictional claims in published maps and institutional affiliations. 